\title{
Geophysical and biogeochemical observations using BGC Argo floats in the western North Pacific during late winter and early spring, Part 2: Biological processes during restratification periods in the euphotic and twilight layers
}

5 Chiho Sukigara ${ }^{1}$, Ryuichiro Inoue ${ }^{2}$, Kanako Sato ${ }^{2}$, Yoshihisa Mino ${ }^{3}$, Takeyoshi Nagai ${ }^{1}$, Andrea J. Fassbender ${ }^{4}$, Yuichiro Takeshita ${ }^{5}$, and Eitarou $\mathrm{Oka}^{6}$

${ }^{1}$ Tokyo University of Marine Science and Technology, Tokyo, 1088477, Japan

${ }^{2}$ Japan Agency for Marine-Earth Science and Technology, Yokosuka, 2370061, Japan

$10 \quad{ }^{3}$ Institute for Space-Earth Environmental Research, Nagoya University, Nagoya, 4648601, Japan

${ }^{4}$ NOAA/OAR Pacific Marine Environmental Laboratory, Washington, 98115, USA

${ }^{5}$ Monterey Bay Aquarium Research Institute, California, 95039, USA

${ }^{6}$ Atmosphere and Ocean Research Institute, The University of Tokyo, Kashiwa, 2778564, Japan

15 Correspondence to: Chiho Sukigara (csukig0@kaiyodai.ac.jp)

\begin{abstract}
Two Argo floats equipped with oxygen, chlorophyll (Chl), backscatter, and nitrate sensors conducted daily vertical profiles of the water column from a depth of $2000 \mathrm{~m}$ to the sea surface in the western North Pacific from January to April of 2018. Data for calibrating each sensor were obtained via shipboard sampling that occurred when the floats were deployed and recovered. Float backscatter observations were converted to particulate organic carbon (POC) concentrations using an empirical relationship derived from contemporaneous float profiles of backscatter and shipboard observations of suspended organic carbon particles. During the float deployment periods, repeated meteorological disturbances (storms) passed over the study area and caused the mixed layer to deepen. During these events, nitrate was entrained from deeper layers into the surface mixed layer, while $\mathrm{Chl}$ and POC in the surface mixed layer were redistributed into deeper layers. After the storms, the upper layer gradually restratified, nitrate concentrations in the surface layer decreased, and Chl and

25 POC concentrations increased. When the floats observed the same water mass, the net community production within the euphotic layer (0-70 m), determined from the increases in POC, was 126-664 $\mathrm{mg} \mathrm{C} \mathrm{m}^{-2} \mathrm{~d}^{-1}\left(10.5-55.3 \mathrm{mmol} \mathrm{C} \mathrm{m}^{-2} \mathrm{~d}^{-1}\right)$ close to the values reported from a nearby area. The $\mathrm{C} / \mathrm{N}$ ratio of the increase in POC and the decrease in nitrate was closed to the Redfield ratio, which indicates that the sensors were able to observe the net biochemical processes in this area despite the relatively low concentrations of nitrate and POC. To determine the fate of particles transported from the surface ocean to the twilight layer, the ratio of oxygen consumption and nitrate regeneration rates were compared. This $\mathrm{O}_{2} / \mathrm{N}$ ratio approached the Redfield ratio when the floats followed the same water mass continuously, but the consumption rate of POC was significantly lower than what would be expected based on the oxygen consumption and nitrate release rates. This suggests that dissolved organic carbon was the main substrate for the respiration in the twilight layer.
\end{abstract}


https://doi.org/10.5194/bg-2021-116

Preprint. Discussion started: 19 May 2021

(C) Author(s) 2021. CC BY 4.0 License.

\section{Introduction}

35 Particulate matter in the ocean plays an important role in the global carbon cycle. Sinking organic particles transport carbon from the surface to the ocean interior, sequester carbon in the deep ocean, and act to lower the atmospheric $\mathrm{CO} 2$ concentration (Sarmiento and Gruber, 2006; Giering et al., 2020). A series of events associated with organic particle production in the euphotic zone, sinking through the water column, and remineralization beneath the surface layer is referred to as the "biological pump" (Volk and Hoffert, 1985; Giering and Humphreys, 2018). The vertical transport of particulate organic carbon (POC) has mainly been ascribed to the gravitational sinking of particles (Sanders et al., 2014; Seigel et al., 2016; Boyd, et al., 2019; Resplandy, et al., 2019).

The crucial factor for the magnitude and efficiency of the biological pump is the sinking velocity of particles. These velocities span over an order of magnitude, between ten to a few hundred meters per day (Turner 2002; Armstrong et al., 2009), and may be determined by their size, shape, and chemical composition (Wilson et al., 2008; Ploug et al., 2008;

45 Iversen and Ploug, 2010; Sukigara et al., 2019). Fast-sinking particles (i.e., $>20 \mathrm{~m} \mathrm{~d}^{-1}$ ) could efficiently transport POC to the ocean interior with little remineralization over a short period of time (Billett et al., 1983). Conversely, slow-sinking and suspended particles are likely remineralized at shallow depths, returning CO2 to the water column and limiting the efficiency of the biological pump (Buesseler et al., 2007). It is important to investigate the distribution and dynamics of slow-sinking and suspended particles, as well as fast-sinking particles, to clarify their contributions to the marine carbon cycle (Alldredge and Silver, 1988; Kwon et al., 2009, Alonso-González et al.,2010).

Presently, there are not enough particle observations in the ocean to comprehensively study their distributions and behaviors. One key reason for this is the difficulty associated with observing the behavior of sinking or suspended particles in the water column. Discrete observations require several liters of water to be collected and filtered from multiple depths to determine the amount and distribution of POC in the water column. Furthermore, the temporal and spatial resolution of the data have

55 been low due to the challenges associated with ship-borne observations during stormy weather. However, it has become possible to estimate the amount of POC from observations by optical sensors (e.g., backscatter) in the last decade (Briggs et al., 2011; Cetinić et al., 2012; Dall'Omlo et al., 2014; Briggs et al., 2020). It is hoped that the growing use of these sensors on Argo floats will make it possible to acquire data during any season and supply enough information to study particle transport in more detail.

60 In recent years, carbon efflux to the ocean interior associated with the seasonal deep mixing of the surface layer has been reported (Dall'Olmo et al., 2016; Lacour et al., 2019). The mixed layer deepens owing to the effect of wind and heat loss to the atmosphere from winter to early spring (Price et al., 1986). This deep mixing exports particulate and dissolved matter below the euphotic zone (i.e., the mixed layer pump, MLP, Gardner et al., 1995). It is noteworthy that the MLP can export suspended and slow- sinking particles, as well as dissolved matter, which cannot reach the mesopelagic zone. During deep 65 winter mixing in the high latitudes, carbon exported via the MLP is $\sim 23 \%$ of the carbon exported gravitationally by fast- 
https://doi.org/10.5194/bg-2021-116

Preprint. Discussion started: 19 May 2021

(c) Author(s) 2021. CC BY 4.0 License.

(c) (i)

sinking particles, on average (Dall'Olmo et al., 2016). Nevertheless, literature on how the MLP influences the global carbon cycle is limited.

In this study, a combination of shipboard and Biogeochemical (BGC) Argo floats was used to make winter-spring observations of physical and biogeochemical processes in the subtropical region south of the Kuroshio Extension (KE) in the

70 western North Pacific. This is a part of the subtropical mode water (STMW) formation region that is known to develop a deep mixed layer (300-400 m) during late winter (Hanawa and Tally, 2001; Qiu et al., 2006, 2007). Additionally, an increase in phytoplankton over a short period of a few weeks in early spring due to the entrainment of nutrients from lower depths to the surface by the deep mixing has been reported (Sukigara et al., 2011). Our study aimed to observe the seasonal transition from a well-mixed, winter water column to the spring warming and stabilization of the water column followed by

75 the stimulation of primary productivity associated with light and nutrient replete conditions. We also explored the transport of POC from the surface mixed layer into the subsurface layer and its fate in the remnant (twilight) layer (Lacour et al., 2019) based on backscattering observations.

\section{Materials and Methods}

\subsection{Study area and shipboard observations}

80 In western boundary current regions, where mesoscale eddies frequently occur, high oceanic heat loss during winter results in a deep mixing layer, leading to the formation of mode water and the oceanic uptake of large amounts of $\mathrm{CO}_{2}$. Moreover, deep mixing of the water column brings nutrients from the base of the seasonal pycnocline, supporting active primary productivity and episodic particulate subduction by the MLP.

Data presented here were collected during two cruises (KS-18-1, January 18-30, 2018, and KS-18-4, April 20-May 1, 2018)

85 aboard the R/V Shinsei-maru. Ship-based sampling was performed using a rosette equipped with twenty-four 12-L Niskin bottles and a 9PLUS conductivity-temperature-depth (CTD) sensor and an SBE43 oxygen sensor (Sea-Bird Scientific, USA). We collected CTD observations from $2000 \mathrm{~m}$ to the sea surface at the deployment location $\left(33^{\circ} 15^{\prime} \mathrm{N}, 1^{\circ} 2^{\circ} 30^{\prime} \mathrm{E}\right.$; station C005 during KS-18-1) of both BGC-Algo floats (WMO 2903329 and 2903330) and at the recovery location (35³1' N, $143^{\circ} 11^{\prime} \mathrm{E}$; station C002 during KS-18-4) of one of the floats (WMO 2903329) (Fig. 1). Water samples for salinity, nutrients,

90 dissolved oxygen (DO) concentration, chlorophyll a (Chl a), and POC were collected to calibrate sensors on the CTD and floats.

\subsection{Float measurements}

Two Navis BGC Autonomous Profiling floats (Sea-Birds Scientific, USA) each equipped with a CTD (SBE $41 \mathrm{cp}$ ), optical

DO sensor (SBE 63), nitrate sensor (DeepSUNA); and a sensor that measures chlorophyll (Chl) fluorescence, 700-nm optical 
https://doi.org/10.5194/bg-2021-116

Preprint. Discussion started: 19 May 2021

(C) Author(s) 2021. CC BY 4.0 License.

(c) (i)

backscatter, and fluorescent dissolved organic matter (fDOM; MCOMS, WETLabs, USA) were used to collect data from January 28-April 20, 2018 (Fig. 1). The floats were programmed to profile every day throughout the observation period.

In the case of DO, the sensor output values were first converted to oxygen concentration following standard protocols outlined in "Processing Argo Oxygen data at the DAC level" (version 2.3.1), using adjusted salinity data based on "Argo

100 Quality Control Manual for CTD and Trajectory Data" (version 3.3). Oxygen concentrations from each float's first profile were compared with CTD observations made at the time of the float deployments. Using a region of the water column in which the oxygen gradient was less than $0.2 \mu \mathrm{mol} \mathrm{O} \mathrm{kg}^{-1} \mathrm{dbar}-1$, a linear regression between float and CTD values was used to determine the gain for the float sensor (Takeshita et al., 2013). A drift correction was determined for each $0.01 \mathrm{~kg}^{-3}$ of potential density $\left(\sigma_{\theta}\right)$, larger than $27.5 \sigma_{\theta}$, using the difference in oxygen concentration between the last float profile and the

105 CTD profile at the time of float recovery. The gain-corrected float oxygen data were then adjusted at each time step by applying the average drift rate to the entire profile over time.

For nitrate, the sensor output values were converted to nitrate concentration following standard protocols outlined in "Processing Bio-Argo nitrate concentration at the DAC level" (version 1.1). The optical wavelength offset, which accounts for the uncertainty in the wavelength registration of the diode array spectrometer, was adjusted to minimize the difference

110 between the discrete and sensor nitrate from the deployment cast. Corrected nitrate concentrations were calculated using the new optical wavelength offset. Subsequent data quality control was implemented using MBARI's SAGE software (Maurer et al. in review), following Johnson et al. (2017).

\subsection{POC measurements}

115 Water samples for POC were collected from the float deployment and recovery stations. Seawater (5-7 L) was collected from a Niskin bottle into a pre-washed soft polyethylene tank through a pre-washed silicon tube. Water samples (n =66) were filtered through pre- combusted $\left(450^{\circ} \mathrm{C}\right.$ for $4 \mathrm{~h}$ ) Grade GF/F Whatman 47-mm glass filters (Cytiva Life Sciences, USA). Filters were stored in pre-combusted aluminum foil at $-20^{\circ} \mathrm{C}$ for chemical analyses. Before analysis, samples were fumed with hydrochloric acid for $12 \mathrm{~h}$ to remove particulate inorganic carbon (e.g., calcium carbonate) before acid was

120 removed using a vacuum desiccator and samples were then dried in the convection oven at $60^{\circ} \mathrm{C}$ overnight $(12 \mathrm{~h})$. Filters were packed in tin cups before analysis using an elemental analyzer (FLASH EA1112, Themo Fischer Scientific, USA). Alanine and glutamine acid (FUJIFILM Wako Pure Chemical Corp., Japan, Guaranteed Reagent, No.014-01045 and 07400505, respectively) were used for calibration standards $(0.03-0.7 \mathrm{mgC})$ and to assess analyzer stability.

\section{Results}

\subsection{POC versus particulate backscattering coefficient relationship}


https://doi.org/10.5194/bg-2021-116

Preprint. Discussion started: 19 May 2021

(c) Author(s) 2021. CC BY 4.0 License.

The vertical distributions of POC and backscattering ( $b_{b p}$ ) showed similar patterns (Fig. 2a, 2b). Vertical b bp profiles showed spike-like signals in some places, and these signals may suggest the presence of large particles (Bishop and Woods, 2008; Briggs et al., 2011). In contrast, the POC profiles showed no spiked values, which may indicate that the large particles that cause spiked signals were only present to the extent that they did not affect the amount of POC.

A linear relationship was found between the POC concentration and $b_{b p}$ (Fig. 2c). For this comparison, b balues were averaged within $\pm 5 \mathrm{~m}$ of each POC sampling depth between the surface and $800 \mathrm{~m}$ to avoid the influence of spiked values. From depths of 800-2000 m, bbp values were averaged within $\pm 10 \mathrm{~m}$ of each POC sampling depth due to the larger interval of bbp measurement depths. The samples collected during the KS-18-4 cruise showed higher POC concentrations in the

135 shallow layer than the samples collected during the KS-18-1 cruise. These high values seem to reflect the extension of the

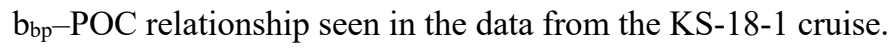

We use the empirical relationship between POC concentration and bbp based on data from both cruises to estimate POC concentrations for each daily float backscatter profile:

$\mathrm{POC}\left[\mathrm{mmol} \mathrm{C} \mathrm{m}{ }^{-3}\right]=\mathrm{b}_{\mathrm{bp}} \times 5628.9+0.2, \mathrm{r}^{2}=0.74$

140 POC $\left[\mathrm{mg} \mathrm{C} \mathrm{m}^{-3}\right]=$ POC $\left[\mathrm{mmol} \mathrm{C} \mathrm{m}^{-3}\right] \times 12 \mathrm{mg} \mathrm{mmol}^{-1}$.

The ranges of the POC concentrations and $b_{b p}$ for these equations were 1-7 $\mathrm{mmol} \mathrm{C} \mathrm{m}^{-3}\left(15-80 \mathrm{mg} \mathrm{C} \mathrm{m}^{-3}\right)$. In a previous study, Cetinić et al. (2012) made similar observations in the North Atlantic and reported the following relationship: POC [mg $\left.\mathrm{C} \mathrm{m}^{-3}\right]=b_{b p} \times 43317-18.4$. Furthermore, in the Southern Ocean, Rambauvill et al. (2017) and Schallenberg et al. (2019) reported that POC $\left[\mathrm{mmol} \mathrm{C} \mathrm{m} \mathrm{m}^{-3}\right]=\mathrm{b}_{\mathrm{bp}} \times 3963.45-0.6$, and POC $\left[\mathrm{mg} \mathrm{C} \mathrm{m}^{-3}\right]=b_{b p} \times 37601-4.95$, respectively. The coefficients in these equations are 30-40\% smaller than those identified in our study domain. One possible reason for this difference may be that the prior studies focused on subarctic and polar regions inhabited by large phytoplankton, while our study was in a relatively oligotrophic subtropical area dominated by small phytoplankton (Fujiki et al., 2015). Small particles are known to be reflected by lower b $b_{b p}$ index values (Morel and Ahn, 1991) and therefore tend to yield higher coefficients in the POC-bbp relationship.

\subsection{Float trajectories and hydrographic conditions}

The two floats, which were deployed at the end of January, moved in a small clockwise trajectory around $33^{\circ} \mathrm{N}$ and $142^{\circ} \mathrm{E}$ for approximately one month (Fig. 1). They then moved southwest for two weeks until mid-March. Around March 13, the floats went south to $32^{\circ} \mathrm{N}$ and then turned north. In late March, they slowed by approximately a week. After April 6, the direction of the floats changed to the northeast, and their speed increased. Several observations just before recovery seem to have been influenced by the KE. After mid-March, float 2903330 was continuously located west of float 2903329.

The potential density anomaly $\left(\sigma_{\theta}\right)$ determined from float profiles of temperature and salinity showed repeated mixing and stratification between the beginning of the observation period and mid-March (Fig. 3a,3b). The surface mixed layer depth was defined as the depth at which $\sigma_{\theta}$ increased by $0.03 \mathrm{~kg} \mathrm{~m}^{-3}$ relative to the values at $10 \mathrm{~m}$. The thickness of the mixed layer 
https://doi.org/10.5194/bg-2021-116

Preprint. Discussion started: 19 May 2021

(c) Author(s) 2021. CC BY 4.0 License.

(c) (i)

160 varied between $<100 \mathrm{~m}$ and $>200 \mathrm{~m}$, with frequent changes until mid-March. These changes were observed by both floats. Intermittent deepening of the mixed layer was likely related to meteorological disturbances (storms) in the region, as the timing between storm events was roughly consistent with the observed mixed layer changes (Inoue et al., in prep.). The 25.3 $\sigma_{\theta}$ contour line, which corresponds to the bottom of the deep mixed layer, gradually deepened over time during this period. The deepest mixed layer was observed on March 18. Float 2903329 then observed a mixed layer at $>300 \mathrm{~m}$ almost daily

165 until March 25. The continuous deepening of the mixed layer exposed $25.3 \sigma_{\theta}$ water at the sea surface and created a thick layer of subtropical mode water. Meanwhile, float 2903330 recorded that the mixed layer changed significantly from March $18-25$, deepening to $>300 \mathrm{~m}$ on March 25 and then rapidly shallowing again, and there was no exposure of the $25.3 \sigma_{\theta}$ water mass, as seen with float 2903329. This difference could be due to the fact that float 2903330 observed water closer to the Kuroshio than float 2903329. Subsequently, the depths of the mixed layer observed by both floats were mostly shallower than $100 \mathrm{~m}$. The temporal variations observed by float 2903329 revealed that the $25.3 \sigma_{\theta}$ water mass was gradually subducted into the middle layer after outcropping.

\subsection{Temporal variations in biogeochemical parameters}

\subsubsection{DO}

175 The DO concentration in the water column was high in the surface euphotic layer and gradually decreased with depth. Variations in upper ocean DO concentrations are caused by air-sea exchange of oxygen with the atmosphere in response to changes in water temperatures, the release of oxygen from phytoplankton photosynthesis in the euphotic layer, and the consumption of oxygen via metabolism beneath the euphotic zone. The vertical profiles of DO from the surface to $400 \mathrm{~m}$ showed a temporal change similar to that of density until mid-March (Fig. 3c,d). Oxygen was transported to the deeper layer

180 with the gradual deepening of the mixed layer during this period. In mid- to late March, the DO concentration near the surface increased a few days after the deepening of the mixed layer. Atmospheric cooling and lower water temperatures may have caused the DO concentration to increase. Later, the surface layer was stratified, and the water temperature began to increase, but the DO concentration remained high. This may be due to the supply of oxygen from biological production in the euphotic zone.

185 The time-series profiles of DO saturation (Fig. 3e,f) showed similar changes to those of the DO concentration. By midMarch, DO was slightly undersaturated in the mixed layer. This is likely due to the redistribution of low-DO water from depth into the mixed layer as a result of deep mixing. Additionally, intermittent DO supersaturation was observed near the surface in late March. From this temporal variation in DO saturation, it can be inferred that oxygen release by biological production actively occurred or water temperature increased during this period. Finally, at 200-400 m, the DO concentration

190 and saturation tended to decrease with time from late March to April (Fig. 3c-f), which may indicate that oxygen was consumed by the degradation of organic matter (OM) in this layer. 


\subsubsection{Nitrate}

The vertical profile of nitrate revealed a high concentration at depths below $200 \mathrm{~m}$ (Fig. 3g, h). The nitrate concentration in the euphotic zone did not increase significantly as the mixed layer deepened in mid-February. From late February to midMarch, an increase in nitrate near the surface was observed during the mixing period. The nitrate concentration in the surface layer increased after the mixed layer deepened from mid- to late March. Comparing the results of the two floats, it was found that the magnitude of the increase in nitrate concentrations was greater for float 2900329, which was located to the east. Subsequently, the nitrate concentrations in the surface layer decreased from the surface to lower concentrations than those before mixing. At this time, it appears that nitrate may have limited primary production. At depths below $200 \mathrm{~m}$, nitrate concentrations gradually increased from late March to early April. This temporal variation in nitrate, in contrast to that of oxygen, may indicate that nutrients were being regenerated by the degradation of organic matter (OM).

\subsubsection{Chl fluorescence}

For Chl (Fig. 3i,j), values above $0.25 \mu \mathrm{g} \mathrm{L}{ }^{-1}$ were found the surface to deeper than the euphotic zone ( $\left.200 \mathrm{~m}\right)$ until midMarch. This Chl distribution may indicate that phytoplankton in the euphotic zone were transported to the twilight zone where they cannot photosynthesize by frequent vertical mixing. In early February, Chl values increased slightly in the surface layer after the deepening of the mixed layer. This suggests that even in winter, when mixing events frequently occur, phytoplankton populations begin to increase once mixing ceases (Siegel, et al., 2002; Behrenfeld, 2010; Mahadevan, et al., 2012; Lacour, et al., 2017; Maúre, et al.). A few days after the deepest mixing occurred in March, a higher Chl fluorescence was observed near the surface. Deep mixing increased nutrient concentrations in the surface layer, and the surface water was stratified for a few weeks. These results suggest that phytoplankton received a stable supply of light, which led to active primary production. However, after April, Chl values deeper than the euphotic zone were lower than before, indicating that the vertical distribution of $\mathrm{Chl}$ from winter to spring was greatly influenced by mixing in the water column.

\subsubsection{POC}

The temporal variation in the POC profiles (Fig. 3k,l) was similar to that of the Chl values (Fig. 3i,j) and a similar trend was also observed for the distribution of oxygen saturation (Fig. 3e,f). The ratio of POC to Chl averaged between depths of 0-70 $\mathrm{m}$ varied from 30-130 $\mathrm{gC}$ gChl-1 throughout the observation period. This was within the range of previously reported for $\mathrm{C} / \mathrm{Chl}$ ratios in the marine surface layer (6-333 $\mathrm{gC} \mathrm{gChl}^{-1}$, Falkowski et al. 1985; Geider, 1987) and indicates that variations in POC concentration correspond well with variations in phytoplankton abundance in the surface layer. The POC concentration also increased in the twilight zone $(70-300 \mathrm{~m})$ as the mixed layer deepened, similar to what was observed for 
https://doi.org/10.5194/bg-2021-116

Preprint. Discussion started: 19 May 2021

(c) Author(s) 2021. CC BY 4.0 License.

(c) (i)

Chl. It is clear that vertical mixing also affected the vertical distribution of POC. The POC concentration in water with a potential density anomaly $>25.4$, which did not outcrop at the surface layer during this observation period (Fig. 3a,b), remained low $(\sim 1 \mu \mathrm{molC} \mathrm{kg}-1)$ and unchanged. In slightly shallower waters $\left(<24.4 \sigma_{\theta}\right)$, POC concentrations increased during the mixing in mid-March. It is likely that this POC production was transported to the twilight zone by subsequent mixing.

\section{Discussion}

\subsection{Primary productivity in the surface layer}

In this study, we observed intermittent mixing and stratification with associated biological activity in the ocean surface layer from winter to spring in 2018. The Chl concentration in the surface layer increased after the deepening of the mixed layer (Fig. 3). This suggests that vertical mixing in this oligotrophic region transports nutrients (such as nitrate) from the deeper layer to the surface, thereby increasing primary productivity (reflected in $\mathrm{Chl}$ and POC concentrations) when the surface layer is stratified. If nutrients entrained to the euphotic zone from the deeper layer were consumed by phytoplankton, the associated production of organic carbon in the euphotic zone would balance nutrient consumption stoichiometrically near the Redfield ratio (106:16, Redfield, 1968), assuming minimal lateral advection. Here, we analyzed temporal variations in biogeochemical parameters in the euphotic zone and the mixed layer to reveal the relationship between surface disturbance and biological activity.

In the study area, the disturbance of the ocean surface layer during winter is caused by strong winds and decreased temperatures due to the passage of low-air-pressure systems. In the early part of 2018, the area around Japan experienced frequent winter pressure systems and repeated cold air inflows due to the passage of low-pressure fronts (Japan Meteorological Agency: https://www.jma.go.jp/jma/index.html). Low-pressure systems passed near the study area 10 times during the observation period, often deepening the mixed layer (Fig. 4a,b). It is worth noting that even if the mixed layer was $>200 \mathrm{~m}$ deep, it would shoal rapidly between disturbances (e.g., after February 5 and 17, and March 7 and 21). The mean concentration of $\mathrm{Chl}$ in the euphotic layer $(0-70 \mathrm{~m})$ increased after each disturbance (Fig. 4c,d). We calculated the surface layer decrease in nitrate and increase in POC concentration after these four disturbance events (Case1-4) and compared the results to what would be expected from Redfield stoichiometry (Table 1). The event periods used for the calculations were defined as the dates of minimum and maximum $\mathrm{Chl}$ concentrations from each storm that caused the deep mixing event. The rates of change in POC and nitrate were defined as the slope of the regression line of mean euphotic zone concentration against time (days) during the event. In all cases, the POC concentrations increased with Chl after each storm (Fig. 4c-f). The rate at which POC increased varied from $0.15-0.79 \mu \mathrm{mol} \mathrm{C} \mathrm{kg}^{-1} \mathrm{~d}^{-1}$ (Table 1).

Net primary productivity values ranging from 296 to $847 \mathrm{mg} \mathrm{C} \mathrm{m-2} \mathrm{d-1} \mathrm{have} \mathrm{previously} \mathrm{been} \mathrm{reported} \mathrm{at} \mathrm{station} \mathrm{S1} \mathrm{(3000'}$ $\mathrm{N}, 145^{\circ} 00^{\prime} \mathrm{E}$ ), slightly south of the float observation area, during winter (February) and spring (April) (Matsumoto et al., 2016). The calculated rate at which POC increased in the surface euphotic layer in this study was $126-664 \mathrm{mg} \mathrm{C} \mathrm{m}^{-2} \mathrm{~d}^{-1}$, 
https://doi.org/10.5194/bg-2021-116

Preprint. Discussion started: 19 May 2021

(c) Author(s) 2021. CC BY 4.0 License.

which is almost within the range of previously reported values. However, nitrate concentrations during the event period decreased in most cases but increased in Case 3 for float 2903330. The $\mathrm{C} / \mathrm{N}$ ratios derived from POC increases and nitrate decreases during each event were calculated and compared with the Redfield ratio. The values were relatively close to the Redfield ratio in Case 2 and 4 for both floats and in Case 3 for float 2903329. Case 1 showed much lower values, and for float 2903330 in Case 3, a positive value was observed.

We also considered whether the changes in POC and nitrate after each event were due to phytoplankton photosynthesis or replacement of water masses using the vertical profiles of density (Fig. 5), nitrate consumption, and POC production. Among the temporal changes in the density profiles of all cases, Case 4 as the most characteristic shape (Fig. $5 \mathrm{~g}, \mathrm{~h}$ ) because the density at 100-400 m changed little after a storm event created a deep mixed layer that reached $350 \mathrm{~m}$. At 0-100 m, density decreased with time, likely because cooling ceased, and the water temperature increased. Inoue et al. (submitted this issue) calculated the vertical one-dimensional heat balance for the Case 4 and showed that the heat flux and change in the surface layer temperature corresponded. After each storm, the near-surface layer in Case 4 became a relatively closed system, and the consumption of nitrate by photosynthesis was reflected in the production of POC, which would have made their ratio close to the Redfield ratio. Nevertheless, it is clear that the pycnocline in Case 3 suddenly shallowed after a storm (Fig. 5e,f). Similar density variations can also be observed in Fig. 3(a,b). From these figures, we found that the isopycnals near the

270 surface, as well as those at depths of $200-400 \mathrm{~m}$, became uniformly shallower. During this period, the floats moved from the edge of a cyclonic eddy toward the center (Inoue et al., submitted this issue) and were strongly affected by the upwelling caused by the eddy over time. Additionally, it can be inferred from the time-series cross-section of nitrate profiles (Fig. 3g,h) that nutrients were supplied from the twilight layer to the euphotic layer by the eddy upwelling. The discrepancy between the ratios of POC production and negative nitrate consumption and the Redfield ratio in the euphotic layer observed by float 2903330 was likely due to the continued supply of nutrients from the lower in the water column, indicating that it was not a closed environment. For float 2903329, the $\mathrm{C} / \mathrm{N}$ ratio in Case 3 was close to the Redfield ratio, but this seemed to be caused by a significant decrease in nitrate concentration on the last day of the observation period. The nitrate concentration for most of this period continued to increase over time, as observed by float 2903330.

In Case 2, the floats were thought to have observed the same water mass near the surface layer because the heat flux and the 280 temperature changes on the surface were generally consistent, although the density of the subsurface layer changed slightly over time (Fig. 5c,d). The distribution of sea surface height (SSH) during this period revealed that the floats were located at the edge of an eddy. The fact that the $\mathrm{C} / \mathrm{N}$ ratio during this period was close to the Redfield ratio likely indicates that the water in the euphotic zone did not exchange much with the surrounding water mass(es).

The temporal variation in the density profiles of Case 1 was similar to that of Case 2 (Fig. 5a,b). However, the C/N ratio in 285 Case 1 was much lower than the Redfield ratio (Table 1). During this period, the floats moved toward the warm water mass on the west side. It can be seen that the shape of the vertical density profiles at depths shallower than $300 \mathrm{~m}$ changed from February 8 for float 2903329 and from February 9 for float 2903330. Based on the density profiles and the SSH distribution, it is likely that the floats at the edge of the eddy, where the gradient of SSH was steeper, observed mixed-layer eddy 
https://doi.org/10.5194/bg-2021-116

Preprint. Discussion started: 19 May 2021

(c) Author(s) 2021. CC BY 4.0 License.

(c) (i)

formation and three-dimensional restratification after the storm (Fox-Kemper et al., 2008). This indicates that when water masses of different densities are adjacent to each other, high-temperature and low-density water rides up to the top of lowtemperature and high-density water to resolve the instability at the surface as cooling ends. In other words, in Case 1, the $\mathrm{C} / \mathrm{N}$ ratios may have differed significantly from the Redfield ratio because of the observation of different surface water masses at the beginning and end of the event period after each storm. The large decrease in nitrate in Case 1 relative to the other cases may be due to the low nutrient concentrations in the warm water observed later in the event. It is likely coincidental that the $\mathrm{Chl}$ and POC during this period showed similar change to those in the other cases.

When considering the stoichiometry of phytoplankton growth after a storm, the ratio of the decrease in nitrate to the increase in POC was close to the Redfield ratio when the structure of the water mass in the surface layer was stable (e.g., not mixing with other water masses). However, if water masses exchanged during these periods or nutrients were supplied from lower in a cyclonic eddy, the values deviated from the Redfield ratio. The relatively low concentrations of nitrate and POC in the surface layer of the subtropical ocean would make sensor-based observations difficult in terms of their accuracy, but our results show that these sensor data can be used to evaluate biogeochemical processes through observations with high temporal resolution.

\subsection{POC degradation in the subsurface layer}

305 In this study, we were able to stoichiometrically observe the production process of OM (photosynthesis) in the surface layer using the biogeochemical sensors attached to Argo floats. We can also use the same approach to observe the decomposition of OM in the subsurface layer. Our two floats repeatedly observed mixing and stratification processes from winter to early spring. The surface suspended OM transported to the subsurface (twilight) layer by deep mixing was considered to be gradually decomposed at depth. If the subsurface water mass did not mix with another water mass, the decomposition of the OM would consume organic carbon and oxygen and regenerate nitrate according to stoichiometric ratios (Anderson, 1995). Therefore, we verified whether or not decomposition could be observed using time-series biogeochemical data from the floats.

To identify the observation period of decomposition, we made observations for more than one week between a deep mixing event and the next. Furthermore, we confirmed a $100 \mathrm{~m}$ region of the water column in which the density was relatively

315 constant, both vertically and temporally. As a result, the mixing event from March 25 was applicable for floats 2903329 and 2903330 (Fig. 6). Rates of change in biogeochemical parameters (DO, POC, and nitrate) averaged within these $100 \mathrm{~m}$ depth domains over time were determined from the slope of the regression line (Table 2). The rates of change in POC and nitrate were quite low compared to that of the primary productivity in the surface layer (Table 1). The results of float 2903329 showed increased DO. It is unlikely that photosynthesis occurs in these layers. Furthermore, the nitrate concentration was

320 almost unchanged in the float 2903329. Only in the float 2903330 were decreases in DO and POC and an increase in nitrate observed, likely because the density was relatively constant and could be observed for eight days. The oxygen consumption 
https://doi.org/10.5194/bg-2021-116

Preprint. Discussion started: 19 May 2021

(c) Author(s) 2021. CC BY 4.0 License.

\section{(c) (i)}

rate $\left(-0.5 \mu \mathrm{mol} \mathrm{kg} \mathrm{kg}^{-1}\right)$ in the 2903330 was comparable to that reported at station S1 (Sukigara et al., 2019). When the stoichiometric ratios were calculated, the $\mathrm{O}_{2} / \mathrm{N}$ ratio was close to the Redfield ratio, but the $\mathrm{C} / \mathrm{N}$ and $\mathrm{C} / \mathrm{O}_{2}$ ratios were significantly lower. This is likely due to the lower expected rate of decline in POC. 2017; Briggs et al., 2020). The method used to estimate the decomposition of POC in this study could not distinguish between suspended particles that were originally included in the water column and new particles added via the fragmentation of settling particles. Therefore, the contribution of particles from settling particles was estimated based on the results of previous studies. Honda et al. (2016) conducted seasonal sediment trap experiments at multiple depths at station S1 and calculated the attenuation factor $(b=1.01)$ by fitting the obtained fluxes at each depth to an attenuation curve (Martin et al., 1987). We calculated the POC lost from settling particles between 200 and $300 \mathrm{~m}$ using the POC flux at $200 \mathrm{~m}$ depth (70 mg $\mathrm{C} \mathrm{m}^{-2} \mathrm{~d}^{-1}$ or $5.8 \mathrm{mmol} \mathrm{C} \mathrm{m}^{-2} \mathrm{~d}^{-1}$ ) from a winter sediment trap experiment and the attenuation factor. As a result, POC $=21 \mathrm{mg}$ $\mathrm{C} \mathrm{m}^{-2} \mathrm{~d}^{-1}\left(1.8 \mathrm{mmol} \mathrm{C} \mathrm{m} \mathrm{m}^{-2} \mathrm{~d}^{-1}\right)$ was expected to be lost between this $100-\mathrm{m}$ water column. However, even if all of this lost POC was decomposed, there would still be $0.02 \mathrm{mmol} \mathrm{C} \mathrm{m}^{-3} \mathrm{~d}^{-1}\left(0.02 \mu \mathrm{mol} \mathrm{C} \mathrm{kg}^{-1} \mathrm{~d}^{-1}\right)$ per meter of depth, which does not explain the oxygen consumption and nitrate regeneration also required in this study.

Assuming that the decomposition in the float 2903330 was correct, the presence of dissolved organic carbon (DOC) should also be considered as a potential reason for the small decrease in POC. The concentration of DOC is reported to be more than 10 times higher than that of POC (Druffel et al., 1992, 1998), so DOC may constitute the majority of the decomposing substrate in the twilight zone. The higher $\mathrm{O}_{2} / \mathrm{N}$ ratio in the float 2903330 than the Redfield ratio may indicate a larger contribution from the decomposition of dissolved organic matter with a relatively high $\mathrm{C} / \mathrm{N}$ ratio. Our floats were also equipped with a sensor to measure fDOM, but the vertical profiles of these sensor values in each case did not show significant changes (not shown). If the concentration of DOC is high, it may be difficult to detect small-scale changes for a few days. To clarify the transport and cycling of materials in the twilight zone in more detail, it is essential to improve the accuracy of the sensors and quantify DOC.

\section{Conclusions}

Two BGC Argo floats equipped with oxygen, Chl, backscatter, and nitrate sensors revealed temporal changes in biological activity associated with the disturbance and restratification of the ocean surface layer caused by the passage of storms in the subtropical western North Pacific during winter and spring. For the backscatter sensor, a continuous vertical profile of the POC concentration could be obtained in a time-series by correcting it with the POC concentrations measured during water sampling. In the surface layer, nutrients were supplied from the lower layer via disturbance, and the Chl fluorescence and POC values reflected an increase in phytoplankton population a few days after disturbance. It is clear that if a water mass is stable, the stoichiometric ratios for the increase in POC and decrease in nitrate will be close to the Redfield ratio. However, because our study area was adjacent to different water masses, such as the edge of an eddy, floats could not always track the 
https://doi.org/10.5194/bg-2021-116

Preprint. Discussion started: 19 May 2021

(c) Author(s) 2021. CC BY 4.0 License.

(c) (i)

355 same water mass. In this case, the stoichiometric ratios of carbon and nitrogen indicated values that differed from the Redfield ratio.

We attempted to observe the decomposition of OM in the twilight layer using floats. Only in the float 2903330 did the oxygen decrease and nitrate increase. For POC, the change was even less conspicuous than those for oxygen and nitrate. This suggests that the substrate for decomposition was mainly DOC, in addition to POC.

360 The observation area is a subtropical region of mode water formation, where a thick mixed layer of $>300 \mathrm{~m}$ is formed from winter to early spring. During this process, the rapid transport of particles produced in the surface layer to the bottom of the mixed layer was observed by sensors with high vertical resolutions. Meanwhile, temporal variations in the mean POC concentration in each layer revealed that most suspended particles were decomposed within the upper $400 \mathrm{~m}$ water column (Fig. 7). However, a part of this water mass would then be transported as the Subtropical Modal Water to the center of the 365 subtropical gyre where winter mixing is shallow. This represents a sequestration pathway for carbon, whether organic or inorganic. As the mixed layer depth shallows in response to global warming, the amount of carbon that can be stored in this area during winter and spring may decrease. To observe this in detail, it will be necessary to investigate the behavior of DOC and dissolved inorganic carbon, which were not quantified in this study. Fortunately, BGC Argo floats can be equipped with additional sensors, such as $\mathrm{pH}$ and fDOM, that may allow for the quantitative evaluation of various biogenic carbon pools

370 (e.g., Haskell et al., 2020). To observe biogeochemical processes in the ocean and clarify the cycling of materials, it is essential to observe and analyze combined physical, chemical, and biological datasets.

\section{Acknowledgement}

We thank the captain, crew, and scientists of R/V Shinsei-maru of the Japan Agency for Marine-Earth Science and 375 Technology (JAMSTEC). We also thank S. Oshitani, K. Katayama, and H. Tamada at Marine Works Japan Ltd. for their analysis and deck work. We appreciate M. Murata for the nutrient analysis. This experiment was supported by a Grant-inAid for Scientific Research on Innovative Areas (Ministry of Education, Culture, Sports, Science and Technology [MEXT] KAKENHI JP15H05818 and JP15K21710). T. Nagai was supported by a Grant-in-Aid for Scientific Research (MEXT KAKENHI JP16H01590, JP18H04914, JP19H01965, and JP20K20634). A. J. Fassbender and Y. Takeshita were supported 380 by the David and Lucile Packard Foundation/MBARI.

\section{References}

Alldredge, A. L., Silver, M. W.: Characteristics, dynamics and significance of marine snow. Progress in Oceanography, 20 (1), 42-82, doi:10.1016/0079-6611(88)90053-5, 1988. 
https://doi.org/10.5194/bg-2021-116

Preprint. Discussion started: 19 May 2021

(c) Author(s) 2021. CC BY 4.0 License.

(c) (i)

Alonso-González, I. J., Arístegui, J., Lee, C., Sanchez-Vidal, A., Calafat, A., Fabrés, J., Sangrá, P., Masqué, P., Hernández-

Guerra, A., Benítez-Barrios, V.: Role of slowly settling particles in the ocean carbon cycle. Geophysical Research Letters, 37 , L13608, doi:10.1029/2010GL043827, 2010.

Anderson L. A.: On the hydrogen and oxygen content of marine phytoplankton. Deep Sea Research I 42 (9): 1675-1680, 1995.

Baker, C. A., Henson, S. A., Cavan E. L., Giering S. L., Yool, A., Gehlen, M., Belcher, A., Riley, J. S., Smith, H. E.,

Sanders, R.: Slow-sinking particulate organic carbon in the Atlantic Ocean: Magnitude, flux, and potential controls. Global Biogeochemical Cycles, 31, 1051-1065, doi:10.002/2017GB005638, 2017.

Behrenfeld, M. J.: Abandoning Sverdrup's Critical Depth Hypothesis on phytoplankton blooms. Ecology, 91 (4), 977-989, 2010.

Billet, D. S. M., Lampitt, R. S., Rice, A. L., Mantoura, R. F. C.: Seasonal sedimentation of phytoplankton to the deep sea benthos. Nature, 302, 520-522, doi:10.1038/302520a0, 1983.

Bishop, J. K. B., Wood, T. J.: Particulate matter chemistry and dynamics in the twilight zone at VERTIGO ALOHA and K2 sites. Deep-Sea Research I, 55, 1684-1706, doi:10.1016/j.dsr.2008.07.012, 2008.

Boyd, P. B., Claustre, H., Lévy, M., Siegel, D. A., Weber, T.: Multi-faceted particle pumps drive carbon sequestration in the ocean. Nature, 568, 327-335, doi:10.1038/s41586-019-1098-2, 2019.

400 Briggs, N., Perry, M. J., Cetinić I., Lee, Craig, D’Asaro, E., Gray, A. M., Rehm, E.: High-resolution observations of aggregate flux during a sub-polar North Atlantic spring bloom. Deep-Sea Research I. 58, 1031-1039, doi:10.1016/j.dsr.2011.07.007, 2011.

Briggs, N., Dall'Olmo, Claustre, H.: Major role of particle fragmentation in regulating biological sequestration of $\mathrm{CO} 2$ by the oceans. Science, 367, 791-793, doi:10.1126/science.aay1790, 2020.

405 Buesseler, K. O., Antia, A. N., Chen, M., Fowler, S. W., Gardner, W. D., Gustafsson, O., Harada, K., Michaels, A. F., Rutgers van der Loeff, M., Sarin, M., Steinberg, D. K., Trull, T. W.: An assessment of the use of sediment traps for estimating upper ocean particle fluxes. Journal of Marine Research, 65 (3), 345-416, 2007.

Dall'Olmo, G., Mork, K. A.: Carbon export by small particles in the Norwegian Sea. Geophysical Research Letters, 41, 2921-2927, doi:10.1002/2014GL059244, 2014.

410 Dall'Olmo, G., Dingle, J., Polimene, L., Brewin, R. J. W., Claustre, H.: Substantial energy input to the mesopelagic ecosystem from the seasonal mixed-layer pump. Nature Geoscience, 9, 820-823, doi:10.1038/NGEO2818, 2016.

Druffel, E. R. M., Williams, P. M., Bauer, J. E., Ertel, J. R.: Cycling of dissolved and particulate organic matter in the open ocean. Journal of Geophysical Research, 97, 15639-15659, 1992.

Druffel, E. R. M., Griffin S., Bauer, J. E>, Wolgast, D. M., X. -C. Wang.: Distribution of particulate organic carbon and

415 radiocarbon in the water column from the upper slope to the abyssal NE Pacific Ocean. Deep-Sea Research II, 45, 667-687, 1998. 
https://doi.org/10.5194/bg-2021-116

Preprint. Discussion started: 19 May 2021

(c) Author(s) 2021. CC BY 4.0 License.

Falkowski, P. G., Dubinski, Z., Wyman, K.: Growth-irradiance relationships in phytoplankton. Limnology and Oceanography, 30, 311-321, doi:10.4319/lo. 198530.2.0311, 1985.

Fox-Kemper, B., Ferrari, R., Hallberg, R.: Parameterization of mixed layer eddies. Part I: Theory and diagnosis. Journal of

Physical oceanography, 38, 1145-1165, doi:10.1175/2007JPO3792.1, 2008.

Fujiki, T., Sasaoka, K., Matsumoto, K., Wakita, M., Mino Y.: Seasonal variability of phytoplankton community structure in the subtropical western North Pacific. Journal of Oceanography, 72, 343-358. https://doi:10.1007/s10872-015-0346-9, 2015.

Gardner, W. D., Chung, S. P., Richardson, M. J., Walsh, I. D. (1995). The oceanic mixed layer pump. Deep-Sea Research II, $42(2-3), 757-775$.

425 Geider, R., J.: Light and temperature dependence of the carbon to chlorophyll a ratio in microalgae and cyanobacteriaimplications for physiology and growth of phytoplankton. New Phytologist Foundation, 106, 1-34, doi:10.1111/j.14698137.1987.tb04788.x, 1987.

Giering, S. L. C., Humphreys, M. P.: "Biological Pump," in Encyclopedia of Geochemistry, Encyclopedia of Earth Sciences Series, ed W. White. (Cham: Springer), 1-6. doi: 10.1007/978-3-319-39193-9_154-1, 2018.

430 Giering, S. L. C., Cavan, E. L., Basedow, S. L., Briggs, N., Burd, A., Darroch, L. J., Guidi, L., Irisson, J. Iversen, M. H., Kiko, R., Lindsay, D., Marcolin, C. R., McDonnell, A. M. P., Möller, K. O., Passow, U., Thomalla, S., Trull, T. W., Waite, A. M.: Sinking organic particles in the ocean - Flux estimates from in situ optical devices. Frontiers in Marine Science, 6, 123, doi:10.3389/fmars.2019.00834, 2020.

Inoue R., Sukigara, C., Bishop, S., Oka, E., Nagai, T., Takeshita, Y.: Geophysical and biogeochemical observations using

435 BGC Argo floats in the western North Pacific during late winter and early spring, Part 1: Restratification processes of surface mixed layer, submitted this issue.

Iversen, M. H., Nowald, N., Ploug, H., Jackson, G. A., Fischer, G.: High resolution profiles of vertical particulate organic matter export off Cape Blanc, Mauritania: Degradation processes and ballasting effects. Deep-Sea Research I, 57, 771-784, 2010.

440 Johnson, K. S., Plant, J. N., Coletti, L. J., Jannasch, H. W., Sakamoto, C. M., Riser, S. C., Swift, D. D., Williams, N. L., Boss, E., Haëntjens, Tally, L. D., Sarmiento, J. L.: Biogeochemical sensor performance in the SOCCOM profiling float array. Journal of Geophysical Research (Oceans), 122 (8), 6416-6436, doi:10.1002/2017JC012838, 2017.

Hanawa, K., Talley, L. D.: Mode waters. In Siedler G, Church J, Gould J (eds) Ocean Circulation and Climate: Observing and Modeling the Global Ocean, Academic Press, London, UK, pp 373-386, 2001.

445 Haskell, W. Z., Fassbender, A. J., Long, J. S., Plant, J. N.: Annual net community production of particulate and dissolved organic carbon from a decade of biogeochemical profiling float observations in the Northeast Pacific. Global Biogeochemical Cycles, 34 (10), 1-22, doi:10.1029/2020GB006599, 2020.

Honda, M. C., Kawakami, H., Matsumoto, K., Fujiki, T., Mino, Y., Sukigara, C., Kobari, T., Uchimiya, M., Kaneko, R., Saino, T.: Comparison of sinking particles in the upper $200 \mathrm{~m}$ between subarctic station K2 and subtropical station S1 based on drifting sediment trap experiments. Journal of Oceanography., 72, 373-386. doi: 10.1007/s10872-015-0280-x, 2016. 
https://doi.org/10.5194/bg-2021-116

Preprint. Discussion started: 19 May 2021

(c) Author(s) 2021. CC BY 4.0 License.

Kwon E. Y., Primeau, F. W., Sarmiento, J. L.: The impact of remineralization on the air-sea carbon balance. Nature Geoscience, 2 (9), 630-635, doi:10.1038/ngeo612, 2009.

Lacour L., Ardyna, M., Stec, K. F., Claustre, H., Prieur, L., Poteau, A., D’Alcala, M. R., Iudicone, D.: Unexpected winter phytoplankton blooms in the North Atrantic subpolar gyre. Nature Geoscience, 10 (11), 836-839, doi:10.1038/NGEO3035, 2017.

Lacour L., Briggs, N., Claustre, H., Ardyna, M., Dall'Olmo, G.: The intraseasonal dynamics of the mixed layer pump in the subpolar North Atlantic Ocean: A biogeochemical-Argo float Approach. Global Biogeochemical Cycles, 33, 266-281, doi:10.1029/2018GB005997, 2019.

Mahadevan, A,, D’Asarom E., Lee, C., Perry, M. J.: Eddy-driven stratification initiates North Atlantic spring phytoplankton blooms. Science, 337, 54-58, doi:10.1126/science.1218740, 2012.

Martin, J. H., Knauer, G. G., Karl. D. M., Broenkow, W. W.: VERTEX: carbon cycling in the northeast Pacific. Deep-Sea Research Part A, 34, 267-285, 1987.

Matsumoto, K., Abe, O., Fujiki, T., Sukigara, C., Mino, Y.: Primary productivity at the time-series stations in the northwestern Pacific Ocean: is the subtropical station unproductive? Journal of Oceanography, 72, 359-371, 465 doi:10.1007/s10872-016-0354-4, 2016.

Maúre, E. R., Ishizaka, J., Sukigara, C., Mino, Y., Aiki, H., Matsuno, T., Tomita, H., Goes, J. I., Gomes, H. R.: Mesoscale Eddies Control the Timing of Spring Phytoplankton Blooms: A Case Study in the Japan Sea. Geophysical Research Letters, 44 (21), 11115-11124, doi:10.1002/2017GL074359, 2017.

Morel, A., Ahn, Y. H.: Optics of heterotrophic nanoflagellates and ciliates: A tentative assessment of their scattering role in oceanic waters compared to those of bacterial and algal cells. Journal of Marine Research, 49, 177-202, doi:10.1357/002224091784968639, 1991.

Ploug, H. Iversen, M., Fischer, G.: Ballast, sinking velocity, and apparent diffusivity within marine snow and zooplankton fecal pellets: Implication for substrate turnover by attached bacteria. Limnology and Oceanography, 53, $1878-1886,2008$.

Price, J. F., Weller, R. A., Pinkel, R.: Diurnal cycling: Observation and models of the upper ocean response to diurnal 475 heating, cooling and wind mixing. Journal of Geophysical Research, 91(C7), 8411-8427, doi.org/10.1029/JC091iC07p08411, 1986.

Qiu, B., Hacker, P., Chen, S., Donohue, K. A., Watts, D. R., Mitsudera, H., Hogg, N. G., Jayne, S. R.: Observation of the subtropical Mode Water evolution from the Kuroshio extension system study. Journal of Physical Oceanographer, 36, 457473, doi.org/10.1175/JPO2849.1, 2006.

480 Qiu, B., Chen, S., Hacker, P.: Effect of mesoscale eddies on Subtropical Mode Water variability from the Kuroshio Extension System Study (KESS). Journal of Physical Oceanographer, 37, 982-1000, doi.org/10.1175/JPO3097.1, 2007.

Rembauvill, M., Briggs, N., Ardyna, M., Uitz, J., Catala, P., Penkerc’h, C., Poteau, A., Claustre, H., Blain, S.: Plankton assemblage estimated with BGC-Argo floats in the Southern Ocean: Implications for seasonal successions and particle export. Journal of Geophysical Research, 122 (10), 8278-8292, doi:10.1002/2017JC013067, 2017. 
https://doi.org/10.5194/bg-2021-116

Preprint. Discussion started: 19 May 2021

(c) Author(s) 2021. CC BY 4.0 License.

(c) (i)

485 Resplandy, L., Lévy, M., McGillicuddy, D. J.: Effect of Eddy-Driven subduction on ocean biological carbon pump. Global Biogeochemical Cycles, 33 (8), 1071-1084, doi:10.1029/2018GB006125, 2019.

Sanders, R., Henson, S., Koski, M., De La Rocha, C. L.: The biological carbon pump in the North Atlantic. Progress in Oceanography, 129, 200-218, doi:10.1016/j.pocean.2014.04.005, 2014.

Schallenberg C., Harley, J. W., Jansen, P., Davies, D. M., Trull, T. W.: Multi-year observations of fluorescence and

490 backscatter at the Southern Ocean Time Series (SOTS) shed light on two distinct seasonal bio-optical regimes. Frontiers in marine Science, 6, 595, doi:10.3389/fmars.2019.00595, 2019.

Siegel, D. A., Doney, S. C., Yoder, J. A.: The North Atlantic Spring Phytoplankton Bloom and Sverdrup's Critical Depth Hypothesis. Science, 296, 730-733, doi:10.1126/science.1069174, 2002.

Siegel, D.A., Buesseler, K.O., Doney, S.C., Sailley, S.F., Behrenfeld, M.J., Boyd, P.W.: Global assessment of ocean carbon

495 export by combining satellite observations and food-web models. Global Biogeochemical Cycles, 28, $181-196$. doi:10.1002/2013GB004743, 2014.

Sukigara, C., Suga, T., Saino, T., Toyama, K., Yanagimoto, D., Hanawa, K., Shikama, S.: Biogeochemical evidence of large diapycnal diffusivity associated with the subtropical mode water of the North Pacific. Journal of Oceanography, 67, 77-85, doi: 10.1007/s10872-011-0008-5, 2011.

500 Sukigara, C., Mino, Y., Kawakami, H., Honda, M. C., Fujiki, T., Matsumoto, K., Wakita, M., Saino, T.: Sinking dynamics of particulate matter in the subarctic and subtropical regions of the western North Pacific. Deep-Sea Research I, 144, 17-27, doi:10.1016/j.dsr.2018.11.004, 2019.

Takeshita, Y., Martz, T. R., Johnson, K. S., Plant, J. N., Gilbert, D., Riser, S. C., Neill, Craig, Tilbrook, B.: A climatologybased quality control procedure for profiling float oxygen data. Journal of Geophysical Research (Oceans), 118, 5640-5650, 505 doi:10.1002/jgrc.20399, 2013.

Turner, J. T.: Zooplankton fecal pellets, marine snow, and sinking phytoplankton blooms. Aquatic Microbiological Ecology, 27, 57-102, doi:10.3354/ame027057, 2002.

Volk, T., and M. I. Hoffert. 1985. OceanVolk, T., Hoffert, M. I.: Ocean carbon pumps: analysis of relative strengths and efficiencies in ocean-driven atmospheric CO2 changes. pp. 99-110. In: E. Sundquist and W. S. Broecker, [Eds.], The carbon 510 cycle and atmospheric CO2: Natural variations archean to present. AGU, pp. 99-110, 1985.

Wilson, S. E., Steinberg, D. K., Buesseler, K. O.: Change in faecal pellet characteristics with depth as indicators of zooplankton repackaging of particles in the mesopelagic zone of the subtropical and subarctic North Pacific Ocean. DeepSea Research II, 55, 1636-1647, doi:10.1016/j.dsr2.2008.04.019, 2008. 
https://doi.org/10.5194/bg-2021-116

Preprint. Discussion started: 19 May 2021

(c) Author(s) 2021. CC BY 4.0 License.

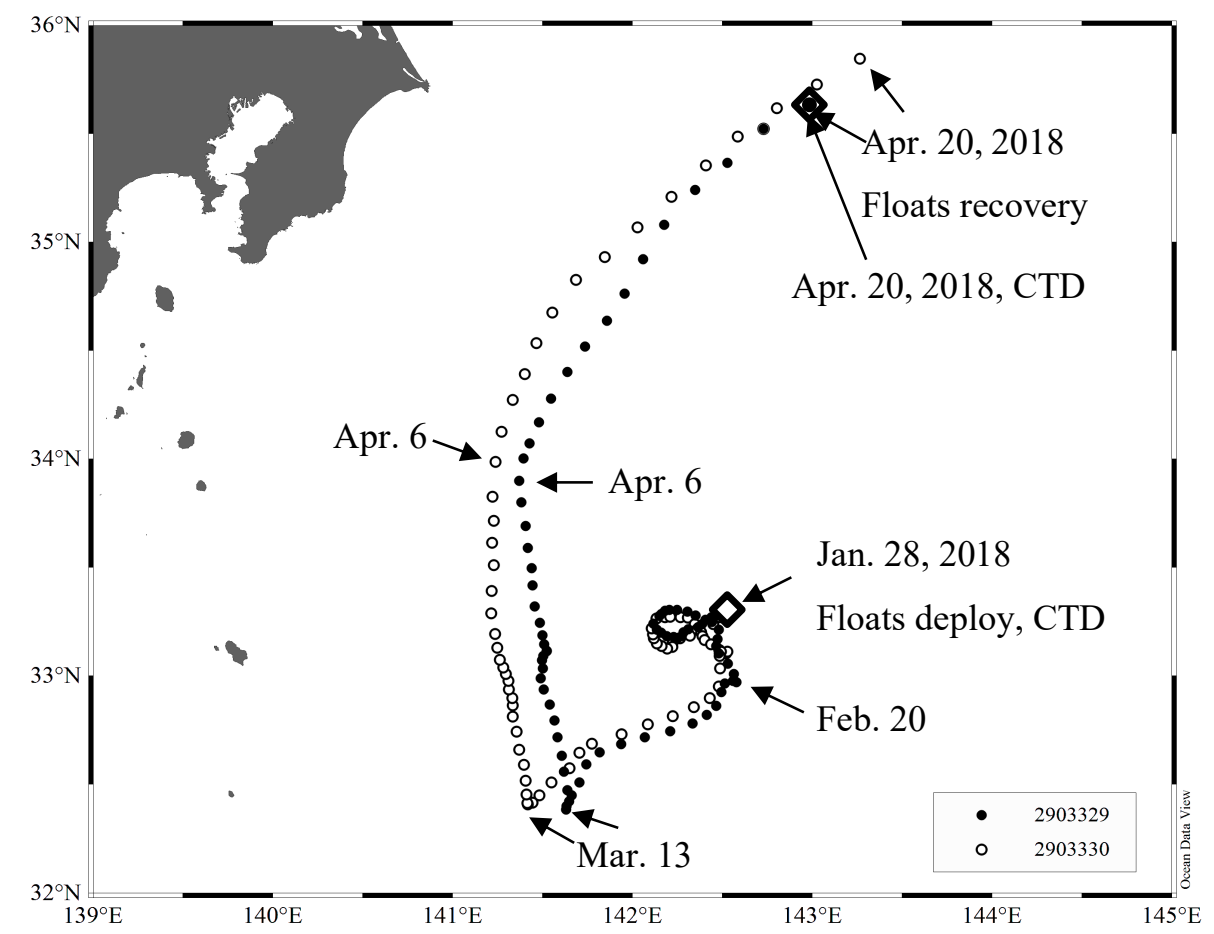

Figure 1: Map of the study area showing the two Argo float trajectories (black circles: Argo 2903329; open circles: Argo 290330) and R/V Shinsei-maru CTD stations where POC samples were collected (open diamonds). 
https://doi.org/10.5194/bg-2021-116

Preprint. Discussion started: 19 May 2021

(c) Author(s) 2021. CC BY 4.0 License.
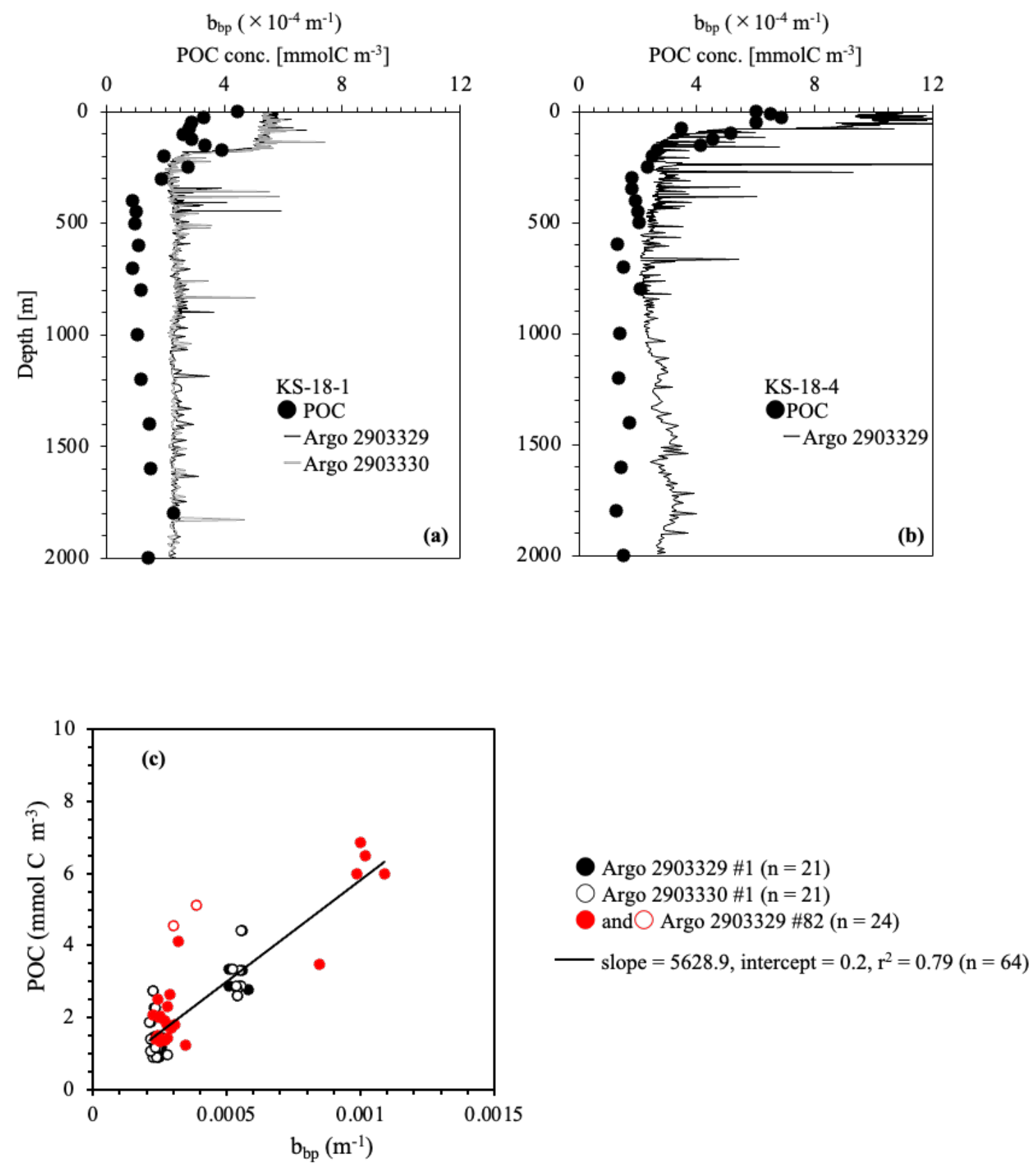

Figure 2: (a) Optical proxy $\left(\mathrm{b}_{\mathrm{bp}}, 700 \mathrm{~nm}\right)$ distribution from the first profile of Argo floats 2903329 and 2903330 and POC sampled on the same day at the float deployment site during KS-18-1 cruise. Black circles show measured POC. Black and gray lines show $b_{b p}$ profiles of Argo float 2903329 and 2903330, respectively. (b) The $b_{b p}$ distribution from the final profile of Argo float 2903329 and POC sampled on the same day at the float recovery site during KS-18-4 cruise. (c) The relationship between $b_{b p}$ and POC. Black and open circles show measurements from the first profile of Argo float 2903329 and 2903330 vs POC. Red and red open circles show measurements from the final profile of Argo float 2903329 vs POC. The black line shows the linear fit to data without two outliers (red open circles). 
https://doi.org/10.5194/bg-2021-116

Preprint. Discussion started: 19 May 2021

(c) Author(s) 2021. CC BY 4.0 License.
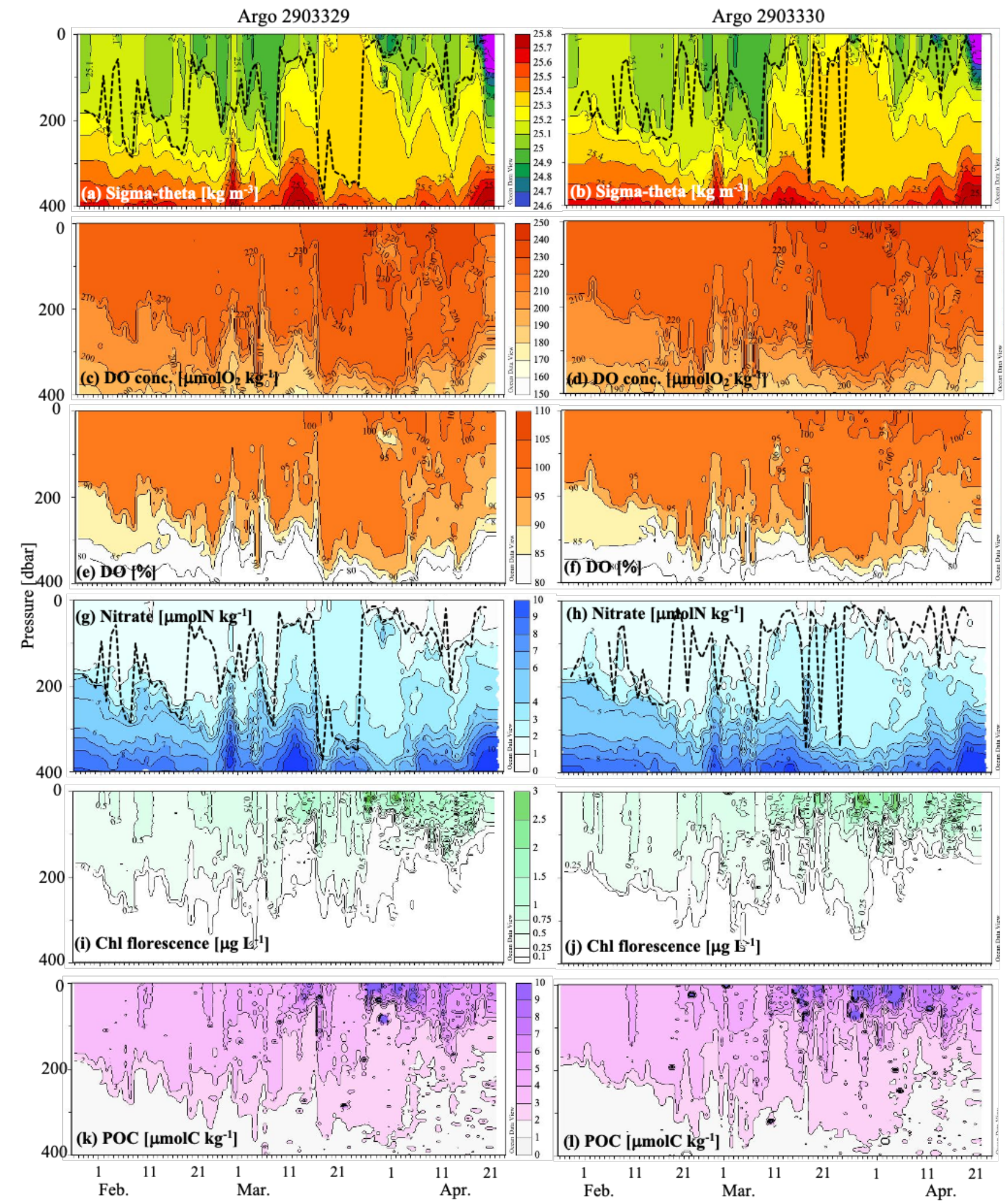
https://doi.org/10.5194/bg-2021-116

Preprint. Discussion started: 19 May 2021

(c) Author(s) 2021. CC BY 4.0 License.

(c) (i)

Figure 3: Time-series of vertical profiles of $(a, b)$ potential densities $\left(\sigma_{\theta}\right),(c, d)$ DO concentrations, $(e, f)$ dissolved oxygen saturation, 530 (g,h) nitrate concentrations, (i,j) Chl fluorescence values, and (k,l) POC concentrations observed by Argo floats 2903329 and 2903330. Mixed layer depths are shown by the black break lines in (a), (b), (g), and (h). The mixed layer depth was defined as difference in $\sigma_{\theta}$ (density) from a depth of $10 \mathrm{~m}$. 
https://doi.org/10.5194/bg-2021-116

Preprint. Discussion started: 19 May 2021

(c) Author(s) 2021. CC BY 4.0 License.

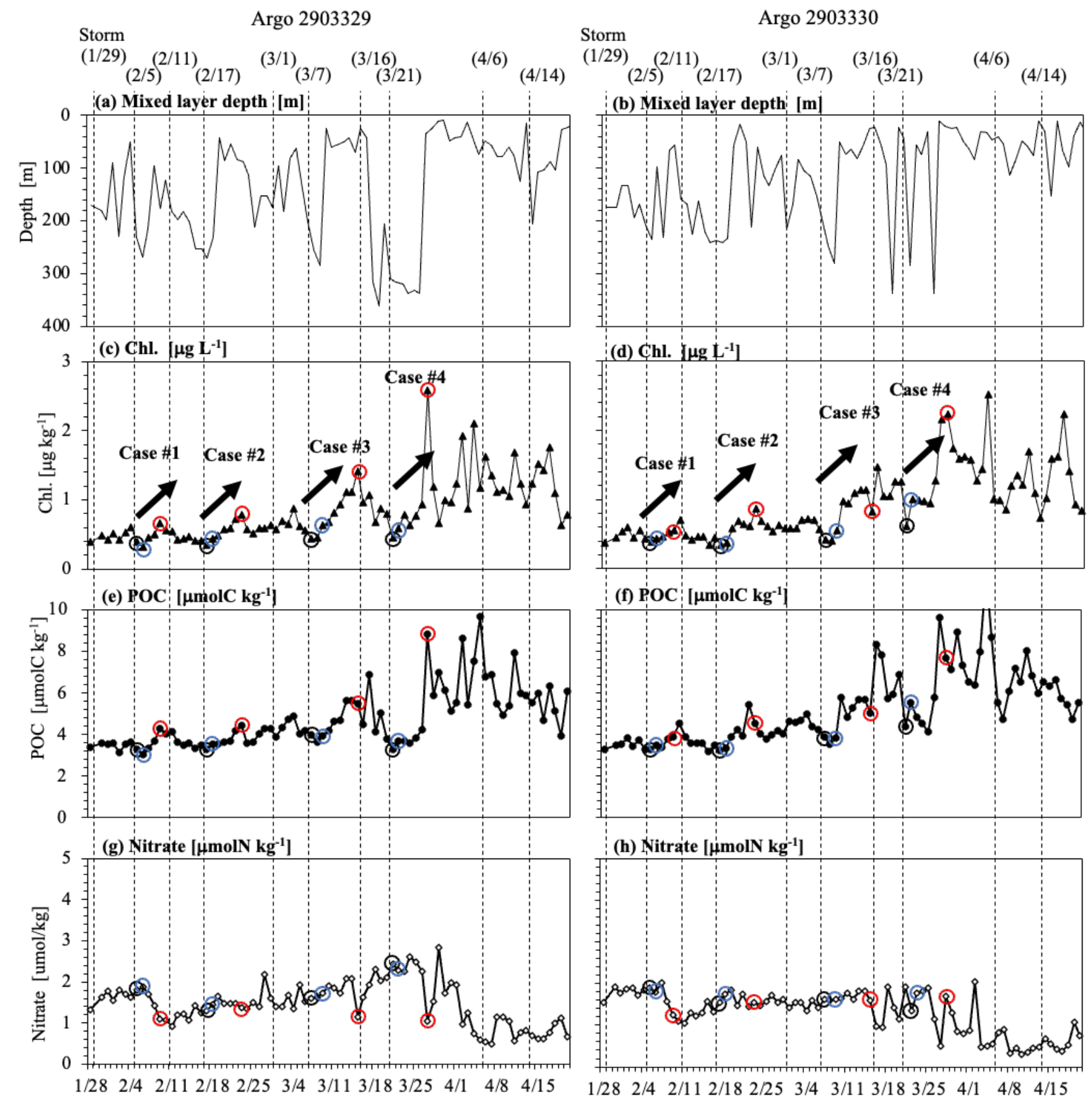

Figure 4: Time-series variation of (a) (b) mixed layer depths, (c) (d) averaged chlorophyll concentration, (e) (f) averaged particulate organic carbon (POC) concentration, (g) (h) averaged nitrate concentration in the euphotic zone $(0$ to $70 \mathrm{~m}$ depth) observed by Argo floats (Argo 2903329 and 2903330). Black dash lines illustrate the time of storm. The thick black arrows in (c) and (d) show when the chl. concentration increased after the storms. Black, blue, and red circles in (c-h) indicate the day of a storm and the subsequent start and end of the chlorophyll increase period, respectively. 
https://doi.org/10.5194/bg-2021-116

Preprint. Discussion started: 19 May 2021

(c) Author(s) 2021. CC BY 4.0 License.

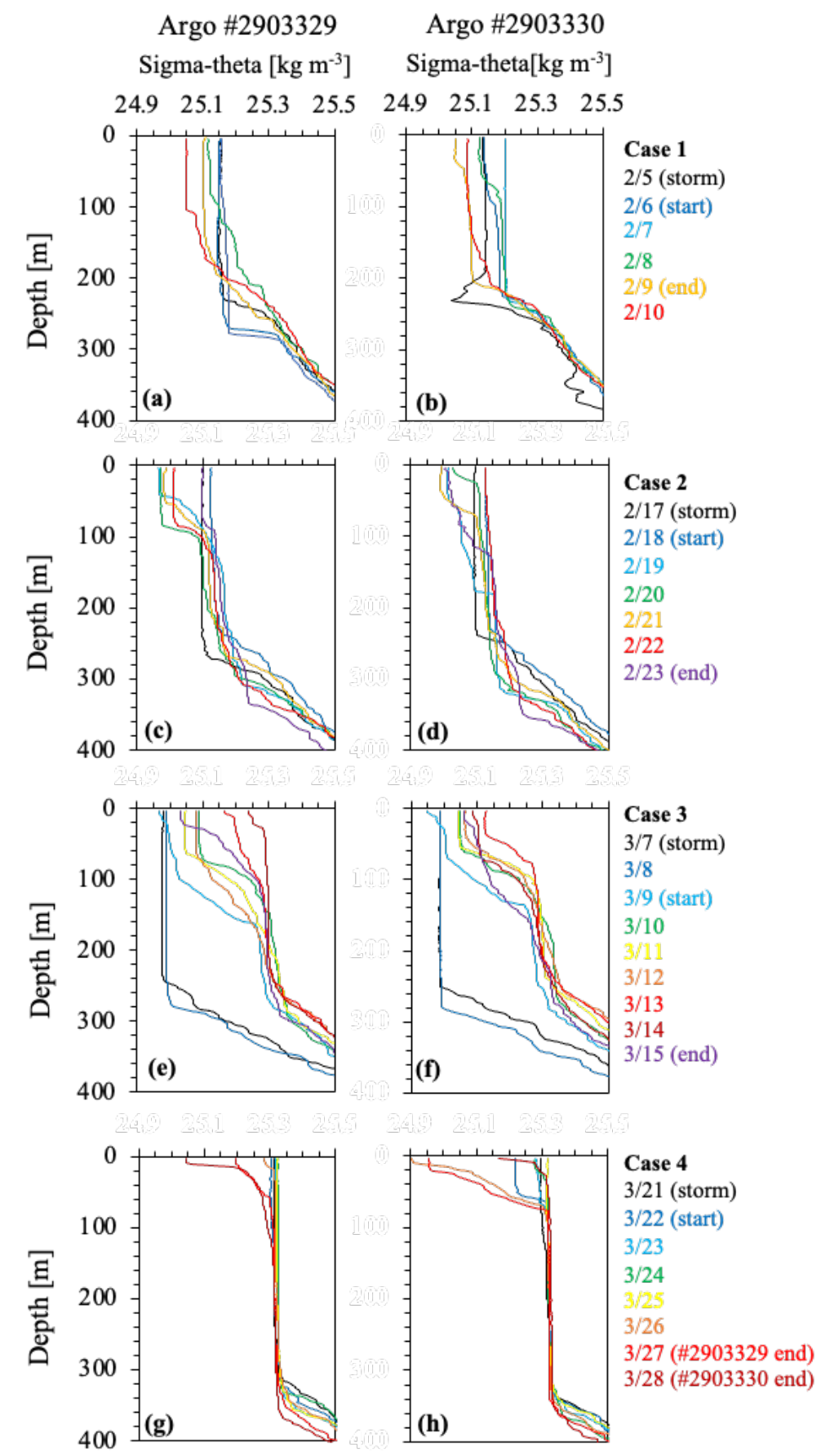

Figure 5: Time-series variation of density $\left(s_{q}\right)$ profiles in each case (1-4) observed by Argo floats 2903329 and 2903330. 
https://doi.org/10.5194/bg-2021-116

Preprint. Discussion started: 19 May 2021

(c) Author(s) 2021. CC BY 4.0 License.
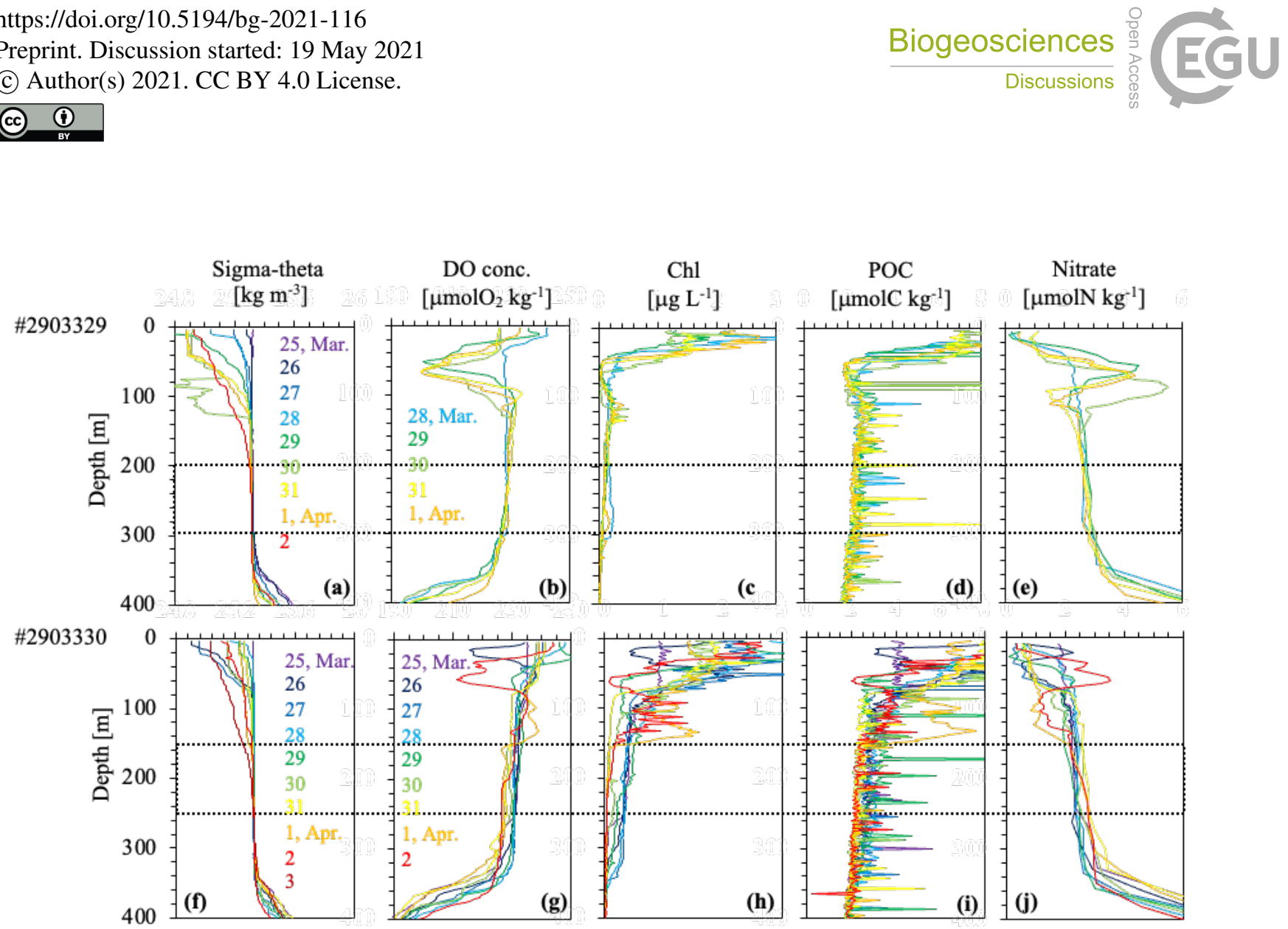

Figure 6: Time-series variation of vertical profiles of (a) (f) density $\left(\sigma_{\theta}\right)$ (b) (g) DO concentration (c) (h) Chl fluorescence (d) (i) POC concentration (e) (j) nitrate concentration (e) and (j) in float 2903329 and 2903330 , respectively. The figures for density show the profile from the mixing to the next. The figures for density show the profile from one mixing event to the next. The biogeochemical parameters show only the periods when the water mass was stable, as determined by the temporal variation in density. The dashed indicate the layer where the water masses were relatively stable. 
https://doi.org/10.5194/bg-2021-116

Preprint. Discussion started: 19 May 2021

(c) Author(s) 2021. CC BY 4.0 License.
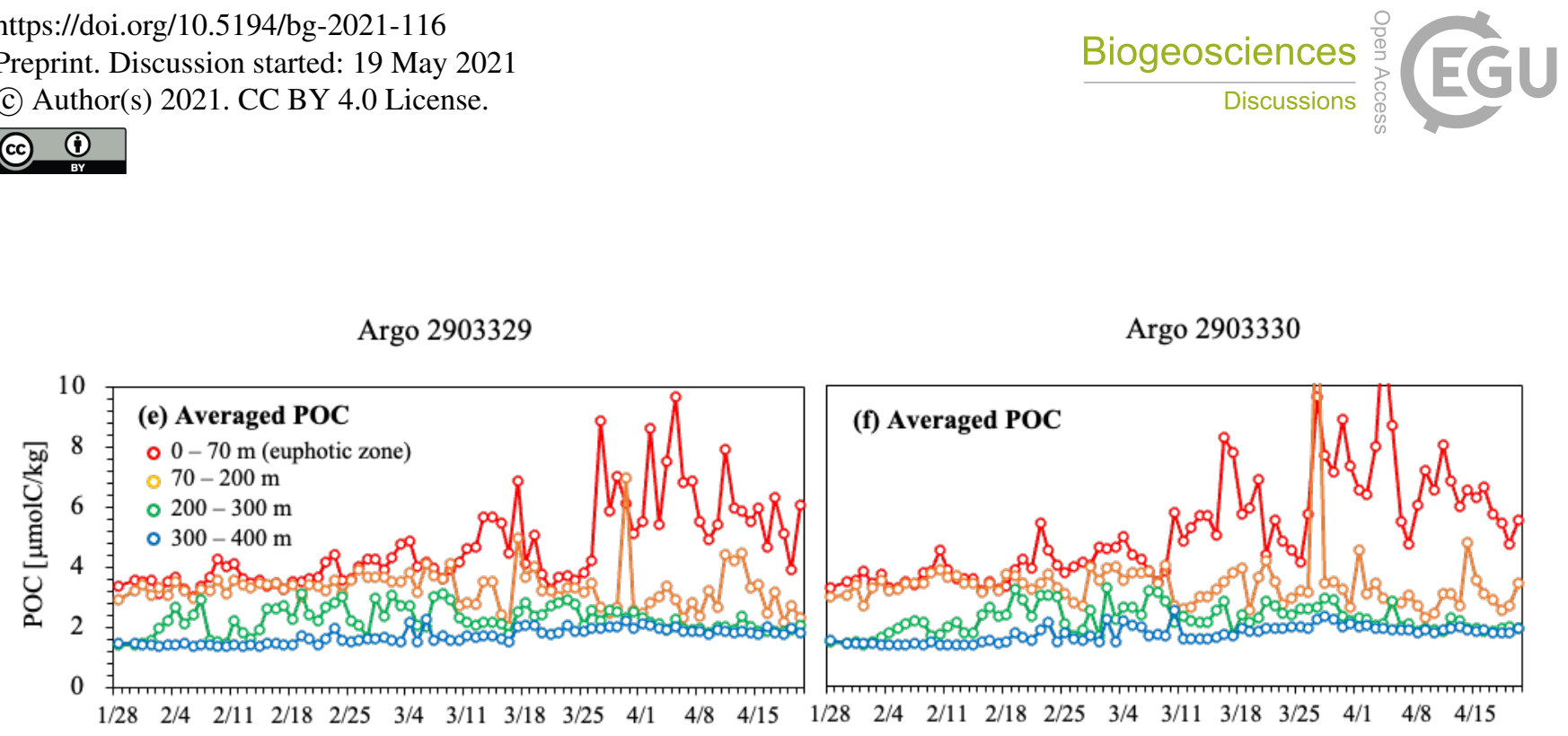

Figure 7: Time-series variation of average POC concentration in layer observed by (a) Argo 2903329 and (b) 2903330. 
https://doi.org/10.5194/bg-2021-116

Preprint. Discussion started: 19 May 2021

(C) Author(s) 2021. CC BY 4.0 License.

Table 1 Stoichiometric comparison in the surface layer in each case.

\begin{tabular}{|c|c|c|c|c|}
\hline Float \# & $\begin{array}{c}\text { Event period } \\
\text { Start - End (days) }\end{array}$ & $\begin{array}{c}\text { POC } \\
{\left[\mu \mathrm{molC} \mathrm{kg}^{-1} \mathrm{~d}^{-1}\right]}\end{array}$ & $\begin{array}{c}\mathrm{NO}_{3}^{-} \\
{\left[\mu \operatorname{molN~kg}^{-1} \mathrm{~d}^{-1}\right]}\end{array}$ & $\mathrm{C} / \mathrm{N}$ \\
\hline \multicolumn{5}{|c|}{ Case 1 (Storm on 5 Feb.) } \\
\hline \#2903329 & $6-9$ Feb. (3 days) & +0.402 & -0.264 & -1.5 \\
\hline \#2903330 & $6-9$ Feb. (3 days) & +0.148 & -0.213 & -0.7 \\
\hline \multicolumn{5}{|c|}{ Case 2 (Storm on 17 Feb.) } \\
\hline \#2903329 & 18 - 23 Feb. (5 days) & +0.184 & -0.028 & -6.7 \\
\hline \#2903330 & $18-23$ Feb. (5 days) & +0.298 & -0.057 & -5.2 \\
\hline \multicolumn{5}{|c|}{ Case 3 (Storm on 7 Mar.) } \\
\hline$\# 2903329$ & $9-15$ Mar. (6 days) & +0.310 & -0.039 & -8.1 \\
\hline \#2903330 & 9 - 15 Mar. (6 days) & +0.148 & +0.012 & +12.7 \\
\hline \multicolumn{5}{|c|}{ Case 4 (Storm on 21 Mar.) } \\
\hline \#2903329 & $22-27$ Mar. (5 days) & +0.785 & -0.181 & -4.3 \\
\hline \#2903330 & 22 - 28 Mar. (6 days) & +0.613 & -0.078 & -7.8 \\
\hline
\end{tabular}


https://doi.org/10.5194/bg-2021-116

Preprint. Discussion started: 19 May 2021

(c) Author(s) 2021. CC BY 4.0 License.

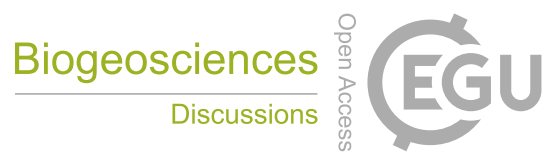

(c) (1)

Table 2: Stoichiometric comparison in the subsurface layer.

560

\begin{tabular}{|c|c|c|c|c|c|c|}
\hline $\begin{array}{l}\text { Float \# } \\
\text { Period }\end{array}$ & Water column & $\begin{array}{c}\mathrm{DO} \\
{\left[\mu \mathrm{molO}_{2} \mathrm{~kg}^{-1} \mathrm{~d}^{-1}\right]}\end{array}$ & $\begin{array}{c}\text { POC } \\
{\left[\mu \mathrm{molC} \mathrm{kg} \mathrm{d}^{-1}\right]}\end{array}$ & $\begin{array}{c}\text { Nitrate } \\
{\left[\mu \mathrm{molN} \mathrm{kg}{ }^{-1} \mathrm{~d}^{-1}\right]}\end{array}$ & $\mathrm{C} / \mathrm{N}$ & $\mathrm{C} / \mathrm{O}_{2}$ \\
\hline
\end{tabular}

\#2903329

565

28 Mar. - 1 Apr.

$200-300 \mathrm{~m}$

$+0.060$

$-0.051$

$+0.004$

\#2903330

25 Mar. - 2 Apr.

$150-250 \mathrm{~m}$

$-0.510$

$-0.065$

$+0.044$

$-1.5+0.13-11.6$

570

References

-0.27 to $-0.51^{*}$

$-$

$-\quad-6.6^{* *}+0.7^{* *}-9.3^{* *}$

575

* Sukigara et al., 2019, ** Anderson, 1995 